\title{
Relationship in Between FDI Inflow and Economic Growth in Kosovo
}

\author{
Xhavit Islami \\ xhavit.islami@uni-pr.edu
}

Enis Mulolli

enis.mulolli@uni-pr.edu

Ass. prof. Nagip Skenderi

nagipskenderi@hotmail.com

University of Prishtina, Faculty of Economics

\begin{abstract}
This study treats the relationship of foreign direct investment (FDI) and economic development in Kosovo. FDI is considered as an important factor of economic growth of places in development, so rightly the question is asked: "Which is the impact of FDI inflow on economic growth of Kosovo?" This study shows the relationship in between FDI inflow and five macroeconomic indicators that have an important role in economic development of Kosovo such as: GDP, GDP per capita, GNI, Exports, and Balance Trade. The data were taken from World Bank and the statistic agency of Kosovo for 2005 to 2014 period. Pearson Correlation technique was used for empirical analysis that is realized with SPSS v. 21.0 statistical program, the results showed that there is a positive relationship in between FDI inflow and GDP growth, whereas there is a negative relationship of FDI inflow and trade balance of Kosovo. This study arguments what is necessary to be done in leading policies to attract foreign direct investment in Kosovo.
\end{abstract}

Keywords: FDI inflow, GDP, economic growth, GNI, Balance trade, Kosovo.

\section{Introduction}

FDI influence on macroeconomic indicators has been dealt by a lot of researchers. FDI role is of a specific importance for places with low economic development that are passing through transition period. The importance of FDI has been noticed in 1980 when borrow-giving loans from commercial banks of places in development failed. As a response to this, most of places changed the access they had on foreign direct investment and created a suitable environment to attract foreign direct investment such as lowering taxes and other facilities through supporting structures in business making (Aitken and Harrison, 1999).

FDI influence on host places is double in technological development also in knowledge advance, through importing new technology such as knowledgeable people and different experiences. FDI is an important tool that facilitates technology transformation from developed places for places in development phase. Also, FDI stimulates inside investment and helps in human capital improvement in host places through know-how transformation (Makki, S. S., \& Somwaru, A. 2004, Romer, P., 1993). According to a study made from (Borensztein, E., et al 1998) realized in 69 undeveloped states, it was confirmed that FDI contributes in economic growth only when host place has enough abilities to absorb the advanced technology. Furtheron, they claimed that their model brings the role of two requests: advanced technology and the ability to gain knowledge from host places. Starting from these findings foreign direct investment are a good chance for economic development in Kosovo, as it has population with youth advantage of age average that offers quick adaptation with technological changes and improvement of knowledge brought from foreign human capital. 
In Kosovo during ten years period have been different variation of foreign direct investment, in $2007 \mathrm{FDI}$ inflow was increased, special merits are given to the investment of releasing the second telephone operation in Kosovo. On the other hand, starting from global crisis in 2008 year FDI started to decrease in Kosovo. Beside the global economic crisis, some other factors impacted on foreign investment failure such as: political crisis in the place, lack of investment security, low infrastructure of business making (roads, energy, water), legal structure non-suitable for business beginning, lack of fighting bureaucracy and corruption which discourages FDI, high level of non-formal economy, non-liberalization of outside trade, low requirement of native trade because of high rate of unemployment and poverty, these factors as well as other factors resulted with a drastic lowering where FDI in 2014 touched almost the floor.

In comparison with 2007 year where FDI reached the amount of about 603 million in 2014 FDI decreased in about 200 million (for at least 202\%). The same trajectory during these years created even the variance of GDP rate, which means that in general view is noticed a positive long-term relationship in between FDI and GDP. Why a huge importance is payed in relation of FDI with GDP indicator? One of the main indicators of this study is GDP which consists in self-consumption, investments, governmental expenses and neto export ( $G D P=C+1+G+E x n)$, so is considered as the main variable that reflects economic growth of a place.

This study gives a ten year period review of the impact of FDI on macroeconomic factors of Kosovo, and helps in problem identification with the purpose of supporting policies orientation in certain economic sectors.

\section{Study objectives:}

To Express empirically the impact of FDI inflow on GDP growth rate, GDP per capit, GNI growth rate, Exports/GDP, and Bilance Trade, for 2005-2014 period.

To show the long-term relationship in between FDI inflow and macroeconomic indicatiors (for 10 year period).

To suggest policies to attract foreign investment in Kosovo.

\section{Literature review}

Before literature review discussion is started, a FDI definition should be given with the purpose that the audience to have a clear picture of its concept. "Foreign direct investment (FDI) refers to long term participation by country A into country B. It usually involves participation in management, joint-venture, transfer of technology and expertise" (Agrawal, G., \& Khan, M. A. 2011).

For FDI relation with macroeconomic indicators, studies of different authors have been divided into two groups: in one side a lot of researchers analyzed the impact of FDI on economic growth of a place, or of a block of places, whereas other authors analyzed the influence of economical and political factors and geography in attracting foreign direct investments. This study will contribute in literature enrichment of the first group the impact of FDI inflow on economic researchers, such as: economic growth factor for places in development (De Mello, 1999; Campos, N. F., \& Kinoshita, Y. 2002; Khan, 2007; Neto et al., 2008; Nosheen, M. 2013; Ali, S., et al 2015; Salim, N. J., et al 2015). Amit Saini et al., (2015) made an analysis for FDI impact on macroeconomic indicators, their results were that FDI inflow has positive and strong relationship with Real GDP, GNI and Export growth while FDI has negative and weak relationship with financial position and Trade openness in SAARC member countries. Also Agrawal, G., \& Khan, M. A. (2011) analysed FDI impact on GDP for 1993-2009 period in China and India, where it was concluded that for each $1 \% \mathrm{FDI}$ growth, there is an increase on GDP for $0.07 \%$ in China and $0.02 \%$ in India. So it is clear that a lot of researcher that analyzed these found a positive relationship in between FDI and economic growth. A lot of researchers agreed with the fact that FDI has an important and positive effect in economic development of the host places through different channels such as creating capital, transferring technology, sharing efficacity, transferring human capital and abilities of advancing knowledge from people of host palces, and so on (Adolfo Maza, et al. 2013). Even Robert, B., (1991), pointed out that FDI has an important role in industrialization process and economic growth of places in development, that explains corporation transactional contribution (CTC) in host places development. 
But it is worth mentioning that not all places of FDI have a positive relationship with economic growth, some places have shown that FDI has a negative role in economic growth (Saltz, 1992; Akinlo 2004; Alaya, M. 2006; Marc, A. 2011), whereas Carkovic, M. V., \& Levine, R. (2002), showed that IHD does not rapid the economic growth of a place. According to existing literature there is a split in understanding the impact of FDI on economic growth of host places. From OECD (2002) report can be seen that not all places in development are able to win from IHD. Host places must assure a minimal eve of capacities such as human capital quality and development of financial sector for FDI absorbing and profitability.

\section{Methodological approach}

The aim of this research is to analyze the empirical relationship in between FDI inflow and some macroeconomic indicators in Kosovo. The relationship is analyzed with correlation method, the general purpose of correlation is to evaluate the relationship in between variables. Our model for the impact of FDI inflow on economic development of Kosovo has been analyzed from six variables: Foreign direct investment, net inflows (\% of GDP) = GDP at market prices (current US\$) / Foreign direct investment, net inflows (BoP, current US\$) ${ }^{1}$; Inside bruto product (GDP) at market prices current in dollar US2; GDP per capita current in dollar US3; GNI current in US dollar4; Export growth/GDP5; and bilanc trade of Kosovo ${ }^{6}$. The technique used to evaluate econometric is Pearson Correlation realized with SPSS 21.0 statistical program.

Data - All data were gathered from World Bank with the exception of data about trade balance which were gathered from Statistical agency of Kosovo. The data are taken from database of World Bank, because it is a trustful source, and majority of the same analysis are based on this database, which allows taking an amount of data and allows preciseness through downloading data in excel. Analysed data are in frequence of one year to ten years (2005-2014).

Table 1. is a reading- guide for coefficient correlation " $r$ " in between variables.

Table 1.

Description of Matrix correlation

\begin{tabular}{lll}
\hline $\begin{array}{l}\text { Value } \\
\text { of } r\end{array}$ & Strength of relationship \\
\hline $\mathbf{1 . 0 0}$ & ris one & It is a perfect relationship between the two variable \\
0.50 & $r$ is greater than 0.00 but less than & It is a positive relationship between the two \\
\hline
\end{tabular}

1 Foreign direct investment refers to direct investment equity flows in the reporting economy. It is the sum of equity capital, reinvestment of earnings, and other capital. Direct investment is a category of cross-border investment associated with a resident in one economy having control or a significant degree of influence on the management of an enterprise that is resident in another economy. Ownership of 10 percent or more of the ordinary shares of voting stock is the criterion for determining the existence of a direct investment relationship. Data are in current U.S. dollars. http://data.worldbank.org/indicator/BX.KLT.DINV.CD.WD

2 GDP at purchaser's prices is the sum of gross value added by all resident producers in the economy plus any product taxes and minus any subsidies not included in the value of the products. Data are in current U.S. dollars. Dollar figures for GDP are converted from domestic currencies using single year official exchange rates. http://data.worldbank.org/indicator/NY.GDP.MKTP.CD 3 GDP per capita is gross domestic product divided by midyear population. GDP is the sum of gross value added by all resident producers in the economy plus any product taxes and minus any subsidies not included in the value of the products. Data are in current U.S. dollars. http://data.worldbank.org/indicator/NY.GDP.PCAP.CD

$4 \mathrm{GNI}$ (formerly GNP) is the sum of value added by all resident producers plus any product taxes (less subsidies) not included in the valuation of output plus net receipts of primary income (compensation of employees and property income) from abroad. Data are in current U.S. dollars. http://data.worldbank.org/indicator/NY.GNP.ATLS.CD

5 Exports of goods and services represent the value of all goods and other market services provided to the rest of the world. They include the value of merchandise, freight, insurance, transport, travel, royalties, license fees, and other services, such as communication, construction, financial, information, business, personal, and government services. They exclude compensation of employees and investment income (formerly called factor services) and transfer payments.

http://data.worldbank.org/indicator/NE.EXP.GNFS.ZS/countries

6 https://ask.rks-gov.net/tregtia-e-jashtme/publikimet/doc_view/1324--statistikat-e-tregtisaeuml-saeuml-jashtme-naeumlntor2015?tmpl=component\&format=raw 


\begin{tabular}{lll}
\hline & 1.00 & Variabiles \\
0.00 & $r$ is zero & There is no relationship between the two variabiles \\
-0.50 & $r$ is between 0.00 and -1.00 & It is a negative relationship between two variables. \\
-1.00 & $r$ is negative one & It is a perfect negative relationship between the two \\
& variables.
\end{tabular}

Source: Amit Saini et al (2015)

\section{Empirical findings}

In all studies made untill now have been found as literature for FDI inflow in economic indicator, it is showed that FDI inflow has a positive or negative influence in economic growth of places. Our research presents positive impact. Even our research presents positive impact of FDI inflow on economic growth in Kosovo.

In table 2. Is presented the relationship in between variables of these study through Correlation Matrix.

Table 2.

Correlation Matrix

\begin{tabular}{|c|c|c|c|c|c|c|c|}
\hline Parameters & Correlations & FDI & $\begin{array}{l}\text { GDP } \\
\text { growth } \\
\text { rate }\end{array}$ & $\begin{array}{l}\text { GDP per } \\
\text { capita }\end{array}$ & $\begin{array}{l}\text { GNI } \\
\text { growth } \\
\text { rate }\end{array}$ & $\begin{array}{l}\text { Exports/ } \\
\text { GDP }\end{array}$ & $\begin{array}{l}\text { Bilance } \\
\text { Trade }\end{array}$ \\
\hline FDI & $\begin{array}{l}\text { Pearson Correlation } \\
\text { Sig. (2-tailed) }\end{array}$ & 1 & $\begin{array}{l}.687^{\star} \\
.028\end{array}$ & $\begin{array}{l}.654 \\
.056\end{array}$ & $\begin{array}{l}.681 \\
.063\end{array}$ & $\begin{array}{l}-.524 \\
.147\end{array}$ & $\begin{array}{l}-.668^{*} \\
.035\end{array}$ \\
\hline GDP growth rate & $\begin{array}{l}\text { Pearson Correlation } \\
\text { Sig. (2-tailed) }\end{array}$ & $\begin{array}{l}.687^{\star} \\
.028\end{array}$ & 1 & $\begin{array}{l}1.000^{* *} \\
0\end{array}$ & $\begin{array}{l}.988^{* *} \\
0\end{array}$ & $\begin{array}{l}-.363 \\
.337\end{array}$ & $\begin{array}{l}-.771^{* *} \\
.009\end{array}$ \\
\hline GDP per capita & $\begin{array}{l}\text { Pearson Correlation } \\
\text { Sig. (2-tailed) }\end{array}$ & $\begin{array}{l}.654 \\
.056\end{array}$ & $\begin{array}{l}1.000^{* *} \\
0\end{array}$ & 1 & $\begin{array}{l}.987^{* *} \\
0\end{array}$ & $\begin{array}{l}-.357 \\
.346\end{array}$ & $\begin{array}{l}-.796^{*} \\
.010\end{array}$ \\
\hline GNI growth rate & $\begin{array}{l}\text { Pearson Correlation } \\
\text { Sig. (2-tailed) }\end{array}$ & $\begin{array}{l}.681 \\
.063\end{array}$ & $\begin{array}{l}.988^{* *} \\
0\end{array}$ & $\begin{array}{l}.987^{* *} \\
0\end{array}$ & 1 & $\begin{array}{l}-.433 \\
.284\end{array}$ & $\begin{array}{l}-.800^{*} \\
.017\end{array}$ \\
\hline Exports/GDP & $\begin{array}{l}\text { Pearson Correlation } \\
\text { Sig. (2-tailed) }\end{array}$ & $\begin{array}{l}-.524 \\
.147\end{array}$ & $\begin{array}{l}-.363 \\
.337\end{array}$ & $\begin{array}{l}-.357 \\
.346\end{array}$ & $\begin{array}{l}-.433 \\
.284\end{array}$ & 1 & $\begin{array}{l}.291 \\
.448\end{array}$ \\
\hline Balance Trade & $\begin{array}{l}\text { Pearson Correlation } \\
\text { Sig. (2-tailed) }\end{array}$ & $\begin{array}{l}-.668^{*} \\
.035\end{array}$ & $\begin{array}{l}-.771^{* *} \\
.009\end{array}$ & $\begin{array}{l}-.796^{*} \\
.010\end{array}$ & $\begin{array}{l}-.800^{*} \\
.017\end{array}$ & $\begin{array}{l}.291 \\
.448\end{array}$ & 1 \\
\hline
\end{tabular}

${ }^{*}$. Correlation is significant at the 0.05 level (2-tailed).

**. Correlation is significant at the 0.01 level (2-tailed). 
In table 2. Is seen that FDI inflow variables, have an important positive relation statistically with GDP growth rate and negative with balance trade, for significance level (0.05). See table.3.

Table 3.

\section{Description according to significance}

\begin{tabular}{|c|c|c|}
\hline Parameters & Sig. $p<0.01 \quad$ Sig. $p<0.05$ & Sig. $p<0.10$ \\
\hline FDI and GDP growth rate & $.687^{\star}$ & \\
\hline FDI and GDP per capita & & .654 \\
\hline FDI and GNI growth rate & & 681 \\
\hline FDI and Balance Trade & $-.668^{*}$ & \\
\hline
\end{tabular}

FDI and GDP growth rate have positive relationship in between that means that with FDI growth will be grown even GDP growth rate and the contrary.

FDI and bilanc trade have negative relationship in between. So with FDI growth is lowered the balance trade. Even this relation has positive impact on economic growth in Kosovo, as the Kosovo has balance trade negative which means that import is bigger than export, so this negative relation in between these variables lowers the difference in between export and import, a condition like that of economic growth can be explained into three methods (place can export more through not raising import, can reducte import through not reasing export, it can raise export and lower import).

Table 4. From table 2 also can be seen the relationship in between other variables.

\begin{tabular}{lll}
\hline Parameters & Sig. $p<0.01$ & Sig. $p<0.05$ \\
\hline & & \\
GDP growth rate and GDP per capita & $1.000^{* *}$ & \\
GDP growth rate and GNI growth rate & $.988^{* *}$ & \\
GDP growth rate and Balance Trade & $-.771^{* *}$ & \\
GDP per capita and GNI growth rate & $.987^{* *}$ & $-.796^{*}$ \\
GDP per capita and Balance Trade & & $-.800^{*}$ \\
GNI growth rate and Balance Trade & & \\
\hline
\end{tabular}

\section{Discussion}

The evaluated coefficient for FDI impact on GDP growth rate is positive and statistically important meaning that it influences the economic development of the place. Also FDI impact has a positive relation with GDP per capita and GNI growth rate but is not statistically important for significance level $(0.05)$. Wheras, negative relation and statistically important FDI has shown the balance trade as well as negative relation but significantly dealing with export /GDP. Singh and June, (1995) found that orientation from export is powerful variable for IHD attraction. Therefore economic policies in Kosovo in order to make the place more attractive and profit-bringing for foreign companies that can invest should be oriented in export. The reason of investment of foreign companies is not the power of buying that our place has in disposition, as it is a place in poverty and high unempoyement, for foreign companies invest in Kosovo for the reason of free employees, as a result of 
lowering the cost of work they realize high profitability or with low costs of their products if it has as objective to win the advantage of completion in host places.

Also, Kosovo integration in trade organizations has a huge role in investment's attraction because for companies that invest their capital in Kosovo, has been facilitated the free conveyance of their products in different places of the world. Now with the signature of Stabilisation and association agreement (SAA) in between BE and Kosovo, which is expected to enter on application in 2016 facilitates the product conveyance in between Kosovo and places of European Union.

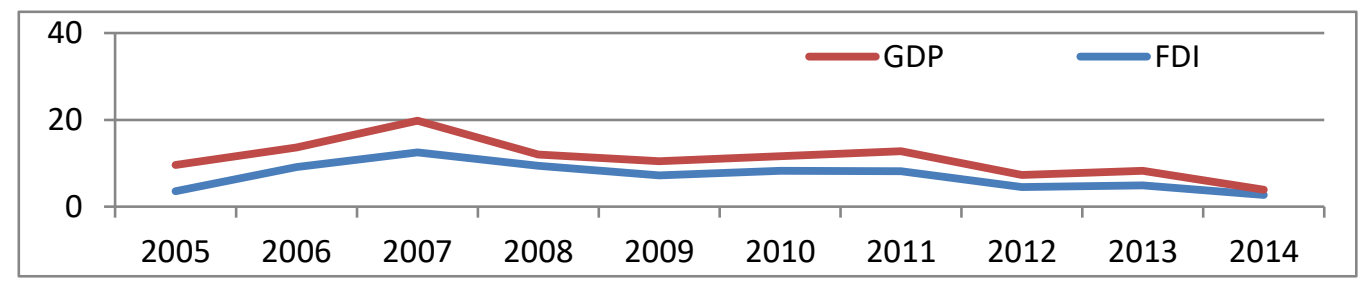

So, a huge importance in foreign direct investment has integration of host place because the main purpose of the companies is the profit, therefore if a company has low cost to trade its products in host place and in neighborhood places it is going to invest in that place. Foreign company investment has positive impact on investing company and for host places because beside the profit of the company that is invested profits the host place, their profit comes mainly from employees movement from foreign company (investitor) in native company, whereas it has negative impact when foreign companies increase the competition of native companies, this competition can not be equal as a result of facilities that foreign companies have from their place. Kosovo has a young population and high rate of unemployment can be turned in technologic development in the region and beyond.

Eventhough in Kosovo continuesly is attemted to liberalize the economic policies with the purpose of following foreign investment still there have not been positive results to raise the investitors investments. The host place in our case Kosovo in order to attract more FDI should made facilitation for foreign investitiors, where foreign investitios should be treated equally with native investitors, to assure free transferring of machines of production as well as to be guaranteed nonownership. So it should leave asides the overwhelmed bureaucratic procedures, to implement a transparent strategy of invesments and to adapt suitable legal insfrastructure to attract high level of FDI and in the same time even economic development of the place.

With the purpose of altering policies in leading the attraction of FDI should be made some changes in tax structure, enterprises should be allowed release from taxes for a certain period of time (grace period in taxes), should be allowed to import equipment producing without costums, to give grants for research in Kosovar trade in order that the investment to have a clear objective and to know the priorities that are offered from the place in case of investment through not causing costs in trade research, to implement guides for credits and value exchange, to be allowed unlimited number of emplyees with knowledge. So, to implement projects that motivate foreign investment and do not allow them to leave and to invest in another country in the region.

In table 3, are shown the relationship in between other: GDP growth rate and GDP per capita, GDP growth rate and GNI growth rate, GDP per capita and GNI growth rate are positively related in between and are statistically important whereas, GDP growth rate and Balance Trade, GDP per capita and Balance Trade, GNI growth rate and Balance Trade have negative relationship statistically important. These results bring to conclusion that export continues to be a black point for Kosovo, and economic policies for investment attraction must be focused especially on export growth and facilitation of product conveyance outside the country. Kosovo is a suitable place to invest but lack of diplomatic relation with other countries, especially with countries that have not recognized Kosovo as an independent country, this is bringing difficulties in investment realization and is creating barriers on foreign investment in Kosovo.

\subsection{The relationship between IHD inflow and GDP real (2005-2014)}


The relationship in between FDI inflow and GDP real is presented graphically in the graphic 1 . Where can be seen in the curve almost parallelly in between the trajectory of FDI inflows and GDP real. So, it can be seen an increase in both of the curves in 2007. Whereas, in the last period the curve has marked a decrease. From this figure can be seen visually the long-term positive relationship in between these variables.

The relationship between IHD inflow and GDP real (2005-2014)

Graphic 1.

\section{Conclusion}

The aim of this study is to measure the relationship in between FDI inflow and economic size of Kosovo. Findings showed that there is a positive long-term relationship in between FDI inflow and economic development. This analysis has been found by measuring the correlation between FDI inflow of five macroeconomic indicators that have an important role in economic development of Kosovo such as (GDP, GDP per capita, GNI, Exports, Balance Trade), for 2005 to 2014 period. Results showed that statistically there is a positive and important relationship in between FDI inflow and GDP growth rate, whereas statistically there is a negative and important relationship with trade balance of Kosovo. Furthermore, correlation in between FDI and GDP per capita, FDI and GNI growth rate is positively related but it has not got a statistical importance for significance level (0.05), whereas, correlation in between FDI and Exports/GDP is negative but without statistical importance. It is worth mentioning that even correlation results of other variables such as: GDP growth rate and GDP per capita, GDP growth rate and GNI growth rate, GDP per capita and GNI growth rate are positively related in between and have statistical importance. On the other hand, GDP growth rate and Balance Trade, GDP per capita and Balance Trade, GNI growth rate and Balance Trade have negative relation which is statistically important. This study makes a significant contribution to the scientific and academic value, to the FDI inflow impact on economic development of Kosovo, in the region and beyond.

\section{Study limitations}

This study contributes to literature enrichment regarding FDI inflow impact on economic growth, but there are some limitations.

- The size of indicators selection, not all the indicators that impact on economic growth of Kosovo are included. For this reason, a huge attention must be payed on the attempt on generalization of data in this study because there are other economic indicators that influence on economic development of the place.

\section{References}

[1] Adolfo Maza, et al. (2013). FDI and economic growth : evidence from the EU at the regional level. Foreign direct investment (FDI) : policies, economic impacts and global perspectives.- New York, NY : Nova Publ., ISBN 9781-62808-403-0, p. 72-101.

[2] Agrawal, G., \& Khan, M. A. (2011). Impact of FDI on GDP: A comparative study of China and India. International Journal of Business and Management, 6(10), p71.

[3] Aitken, B. J., \& Harrison, A. E. (1999). Do domestic firms benefit from direct foreign investment? Evidence from Venezuela. American economic review, 605-618.

[4] Akinlo, A. (2004). Foreign direct investment and growth in Nigeria: An empirical investigation. Journal of Policy Modeling, (26) 627-639.

[5] Alaya, M. (2006). Investissement direct étranger et croissance économique: une estimation à partir d'un modèle structurel pour les pays de la rive sud de la Méditerranée. LES Cahiers de L'IRD, Paris, AUF. 
[6] Ali, S., et al (2015). Impact of FDI and Trade Balance on Economic Growth during 1990-2014, a Case Study of Pakistan. Historical Research Letter, vol.25, pp 25-29.

[7] Amit Saini et al., (2015), "Impact of FDI inflow on economic growth of SAARC economies", International Journal of Engineering, Business and Enterprise Applications, 12(2),, pp. 161-166.

[8] Borensztein, E., De Gregorio, J., \& Lee, J. W. (1998). How does foreign direct investment affect economic growth?. Journal of international Economics, 45(1), 115-135.

[9] Campos, N. F., \& Kinoshita, Y. (2002). Foreign direct investment as technology transferred: Some panel evidence from the transition economies. The Manchester School, 70(3), 398-419.

[10] Carkovic, M. V., \& Levine, R. (2002). Does foreign direct investment accelerate economic growth?. U of Minnesota Department of Finance Working Paper.

[11] De Mello, L. R. (1999). Foreign direct investment-led growth: evidence from time series and panel data. Oxford economic papers, 51(1), 133-151.

[12] Khan, M. A. (2007). Foreign direct investment and economic growth: the role of domestic financial sector (No. 2007: 18). Pakistan Institute of Development Economics.

[13] Makki, S. S., \& Somwaru, A. (2004). Impact of foreign direct investment and trade on economic growth: Evidence from developing countries. American Journal of Agricultural Economics, 86(3), 795-801.

[14] Marc, A. (2011). Is foreign direct investment a cure for economic growth in developing countries? Structural model estimation applied to the case of the south shore Mediterranean countries. Journal of International Business and Economics, 11(4.).

[15] Neto, P., Brandão, A., \& Cerqueira, A. (2008). The impact of FDI, cross-border mergers and acquisitions, and greenfield investments on economic growth. The IUP Journal of Business Strategy, 24-44.

[16] Nosheen, M. (2013). Impact of Foreign Direct Investment on Gross Domestic Product. World Applied Sciences Journal, 24(10), 1358-1361.

[17] OECD (2002). Foreign direct investment for development: Maximising benefits, minimising costs. Paris: Organisation for Economic Co-operation and Development.

[18] Robert, Barro. (1991) Economic Growth in a Cross Section of Countries.. In: The Quarterly Journal of Economics. RePEc:tpr:qjecon:v:106:y:1991:i:2:p:407-43.

[19] Romer, P. (1993). Idea gaps and object gaps in economic development. Journal of monetary economics, 32(3), 543-573.

[20] Salim, N. J., Mustaffa, R., \& Hanafiah, N. J. A. (2015). FDI and Economic Growth Linkages in Malaysia. Mediterranean Journal of Social Sciences, 6(4), 652.

[21] Saltz, I. S. (1992). The negative correlation between foreign direct investment and economic growth in the Third World: theory and evidence. Rivista Internazionale di Scienze Economiche e Commerciali, 39(7), 617-633.

[22] Singh, H., \& Jun, K. W. (1995). Some new evidence on determinants of foreign direct investment in developing countries. World Bank Policy Research Working Paper, (1531). 